\title{
MENINGKATKAN KESEJAHTERAAN SUBJEKTIF PASIEN GAGAL GINJAL KRONIS MELALUI TERAPI KOGNITIF PERILAKUAN RELIGIUS
}

\section{IMPROVING SUBJECTIVE WELL-BEING OF CHRONIC KIDNEY DISEASE PATIENTS WITH RELIGIOUS COGNITIVE BEHAVIOR THERAPY}

\author{
Elda Trialisa Putri \\ Qurotul Uyun \\ Rr. Indahria Sulistyarini \\ Fakultas Psikologi dan Ilmu Sosial Budaya Universitas Islam Indonesia, Yogyakarta \\ Email: eldatrialisa@gmail.com
}

\begin{abstract}
The purpose of this study is to examine the effectiveness of religious cognitive behavioral therapy in improving subjective well-being of chronic kidney disease patients. The hypothesis of the study was that there is a significant difference in the subjective well-being between experimental and control groups. Four chronic kidney disease patients with age between 22-45 years old, Muslim, and suffering chronic kidney disease more than 6 months participated this study. The design of this experiment was a quasi experiment with pretest-posttest control group design and follow up. Data were collected with satisfaction with Life Scale (SWLS) from Diener, Emmons, Larsen and Griffin's Scale (1985) and Positive Affect and Negative Affect Schedule (PANAS) from Watson, Clark, and Tellegen's scale (1988). Independent sample t-test was conducted to analyze the data. The result showed that there was a difference life satisfaction between the experimental and control group $(t=4,287, p=0,005(p<0,01)$. Also, there were difference on an affection score between the experimental and control group $(t=4,407, p=0,005(p<0,01)$.
\end{abstract}

Keywords: religious cognitive behavioral therapy, subjective well-being, life satisfaction, affection, chronic kidney disease

\begin{abstract}
ABSTRAK
Penelitian ini bertujuan untuk mengetahui efektivitas terapi kognitif perilakuan religius untuk meningkatkan kesejahteraan subjektif pasien gagal ginjal kronis yang menjalani hemodialisis. Subjek dalam penelitian ini adalah pasien gagal ginjal kronis yang menjalani hemodialisis lebih dari 6 bulan, laki-laki maupun perempuan, beragama Islam, berusia antara 22-45 tahun $(\mathrm{N}$ kontrol=4, $\mathrm{N}$ eksperimen $=4)$. Desain penelitian ini adalah kuasi eksperimen, dengan pretest-posttest control group design. Penelitian ini menggunakan analisis independent sample t-test. Hasil menunjukkan terdapat perbedaan yang signifikan pada nilai kepuasan hidup dengan $\mathrm{t}=4$,287, $\mathrm{p}=0,005(\mathrm{p}<0,01)$ antara kelompok eksperimen dan kelompok kontrol. Pada skala afeksi terdapat perbedaan yang signifikan antara kelompok kontrol dan eksperimen yaitu $t=4,407, p=0,005(p<0,01)$. Berdasarkan hasil analisis terlihat bahwa terapi kognitif perilakuan religius mampu meningkatkan kesejahteraan subjektif pasien gagal ginjal kronis.
\end{abstract}

Kata Kunci: Terapi kognitif perilakuan religius, kesejahteraan subjektif, kepuasan hidup, afeksi. 
Penyakit ginjal adalah kelainan yang mengenai organ ginjal yang timbul akibat berbagai faktor, misalnya infeksi, tumor, kelainan bawaan, penyakit metabolik atau degeneratif, dan lain-lain (Kementrian Kesehatan RI, 2013). Kelainan tersebut dapat memengaruhi struktur dan fungsi ginjal dengan tingkat keparahan yang berbeda-beda. Pasien mungkin merasa nyeri, mengalami gangguan berkemih, dan lain-lain. Terkadang pasien penyakit ginjal tidak merasakan gejala sama sekali. Pada keadaan terburuk, pasien dapat terancam nyawanya jika tidak menjalani hemodialisis (cuci darah) berkala atau transplantasi ginjal untuk menggantikan organ ginjalnya yang telah rusak parah. Di Indonesia, penyakit ginjal yang cukup sering dijumpai antara lain adalah penyakit gagal ginjal dan batu ginjal.

Gagal Ginjal Kronik (GGK) adalah suatu sindrom klinis yang disebabkan penurunan fungsi ginjal yang bersifat menahun, berlangsung progresif dan cukup lanjut, serta bersifat persisten dan irreversibel (Mansjoer, 2000). GGK didefinisikan sebagai gagal ginjal kronis jika pernah didiagnosis menderita penyakit gagal ginjal kronis (minimal sakit selama 3 bulan berturut-turut) oleh dokter.
Prevalensi gagal ginjal kronis di Indonesia -berdasarkan diagnosis doktersebesar $0,2 \%$. Prevalensi tertinggi di Sulawesi Tengah sebesar 0,5\%, diikuti Aceh, Gorontalo, dan Sulawesi Utara masing-masing $0,4 \%$. Sementara Nusa Tenggara Timur, Sulawesi Selatan, Lampung, Jawa Barat, Jawa Tengah, DI Yogyakarta, dan Jawa Timur masingmasing $0,3 \%$. Prevalensi penyakit gagal ginjal kronis yang didiagnosis dokter meningkat seiring dengan bertambahnya umur, meningkat tajam pada kelompok umur 35-44 tahun $(0,3 \%)$, diikuti umur 45-54 tahun $(0,4 \%)$, dan umur 55-74 tahun $(0,5 \%)$, tertinggi pada kelompok umur $\geq 75$ tahun $(0,6 \%)$. Prevalensi pada laki-laki $(0,3 \%)$ lebih tinggi dari perempuan $(0,2 \%)$, prevalensi lebih tinggi pada masyarakat perdesaan $(0,3 \%)$, tidak bersekolah $(0,4 \%)$, pekerjaan wiraswasta, petani/nelayan/buruh $(0,3 \%)$, dan kuintil indeks kepemilikan terbawah dan menengah bawah masing-masing 0,3\% (Kementrian Kesehatan RI, 2013).

Peningkatan jumlah pasien gagal ginjal kronik tidak diikuti dengan penanganan fisik dan psikis yang lebih baik sehingga banyak pasien gagal ginjal kronik kondisinya memburuk, bahkan menyebabkan kematian (Safitri, 2013). Hal ini juga sejalan dengan hasil wawancara yang dilakukan oleh peneliti se- 
belumnya kepada pasien gagal ginjal kronik bahwa proses dialisis harus dialami pasien selama hidupnya. Dialisis dilakukan 2 kali seminggu selama paling sedikit 4 atau 5 jam per terapi (Sadif, 2013). Terapi hemodialisis pada umumnya akan menimbulkan stres fisik seperti kelelahan, sakit kepala dan keringat dingin akibat tekanan darah yang menurun. Efek ini juga memengaruhi kondisi psikologis pasien di mana pasien gagal ginjal kronik mengalami gangguan dalam proses berpikir dan konsentrasi serta gangguan dalam hubungan sosial.

Penelitian yang dilakukan Safitri dan Sadif (2013) menemukan bahwa terdapat enam gejala yang muncul pada pasien GGK, yaitu kemarahan karena penyakitnya telah membuat dirinya menderita, keputusasaan, ketidakberdayaan, merasa lelah menjalani hemodialisis, merasa lebih baik bila ada dukungan keluarga dan pasrah pada Tuhan yang memberi kekuatan untuk menghadapi penyakitnya. Gejala-gejala yang muncul ini menunjukkan ketidaksiapan pada diri pasien GGK telah mengalami penyakit kronis, sehingga mengalami perubahan hidup yang drastis. Hal ini memengaruhi kesejahteraan subjektif pada pasien GGK di mana terdapat perubahan dalam hidup seperti merasa putus asa, merasa tidak berguna, dan menarik diri dari lingkungan sekitar sehingga kualitas hidup dari pasien GGK juga terlihat menurun.

Permasalahan psikologis yang dialami pasien GGK sudah ditunjukkan dari sejak pertama kali pasien divonis. Kecemasan dan ketakutan adalah reaksi umum terhadap stress penyakit. Perasaan hilang kendali, bersalah dan frustrasi juga turut berperan dalam reaksi emosional pasien. Seren mengungkapkan bahwa kecemasan ber-pengaruh kepada kondisi fisik, kualitas hidup yang buruk, dan perasaan ketidak-berdayaan (Foreze, Martin, Patton, Zadeh \& Kopple, 2010). Penelitian ini juga menemukan bahwa kecemasan mening-kat pada saat pasien akan mulai me-masuki rutinitas dialisis. Hal ini me-nyebabkan penderita menjadi semakin terpuruk dan memengaruhi kondisi fisik-nya. Kesejahteraan subjektif yang rendah ditunjukkan dengan afek positif dan kualitas hidup yang rendah pula sementara afek negatifnya yang tinggi. Afek negatif yang tinggi inilah yang turut memengaruhi kondisi fisik pasien GGK.

Penelitian yang terkait dengan terapi yang digunakan untuk meningkatkan kesejahteraan subjektif pada pasien GGK adalah penelitian Cahyareni (2014), tentang efektivitas pelatihan kebersyukuran untuk meningkatkan 
subjective well being pada pasien gagal ginjal. Penelitian ini melibatkan 16 orang pasien GGK yang menjalani hemodialisis dengan usia berkisar antara 20-35 tahun yang memiliki skor SWLS sedang atau rendah dan afek negatif yang sedang atau tinggi. Hasil dari intervensi yang telah dilakukan adalah pelatihan kebersyukuran mempunyai pengaruh terhadap peningkatan subjective well-being (SWB) pada pasien gagal ginjal. Penelitian lain yang digunakan pada pasien GGK adalah tentang Gratitude Cognitive Behavior Therapy (G-CBT) untuk meningkatkan penerimaan diri pada pasien gagal ginjal kronik yang menjalani hemodialisis oleh Safitri (2013). Hasil dari penelitian ini yaitu G-CBT memberikan pengaruh terhadap peningkatan penerimaan diri pada pasien GGK yang menjalani hemodialisis.

Berdasarkan beberapa penelitian di atas, pasien GGK sudah menerima beberapa macam terapi untuk dapat meningkatkan kondisi pasien GGK. Pasien GGK membutuhkan keadaran dari dalam diri untuk dapat mengubah pola pikir (cognitive) serta mengarahkan emosi yang lebih positif sehingga terbentuk perilaku yang dapat meningkatkan kesejahteraan subjektif.

Terapi kognitif perilakuan mencakup dua tipe intervensi, yaitu intervensi yang difokuskan secara langsung untuk mengubah sisi kognitif, dengan asumsi bahwa hal tersebut akan diikuti oleh perubahan perilaku, serta sebaliknya intervensi yang difokuskan untuk mengubah perilaku, dengan asumsi akan diikuti dengan perubahan kognisi (Sundel \& Sundel, 2005). Koreksi terhadap kesalahan konstruk pikir dapat mengarahkan pada peningkatan kondisi klinis seseorang. Hal ini terlihat dari sisi kognitif subjek yang seringkali menyalahkan dirinya karena sakit yang dimiliki subjek sehingga subjek menjadi lebih sensitif dan mudah tersinggung.

Pendekatan kognitif perilakuan dipercaya memiliki hasil yang lebih optimal bila didukung pendekatan religius. Menurut Ancok dan Suroso (2011), religiusitas merupakan perilaku ritual (ibadah) yang dilakukan individu serta aktivitas lainnya yang didorong kekuatan supranatural guna mendekatkan diri kepada Allah SWT termasuk didalamnya aktivitas yang tampak maupun yang tidak tampak (di dalam hati). Semakin klien merasakan adanya peningkatan dan keyakinan beragama, perubahan positif yang dirasakan cenderung lebih menetap (McCullough \& Larson, 1999). Penelitian Utami (2012) mendapatkan bahwa religiositas memiliki pengaruh terhadap kesejahteraan subjektif pada mahasiswa 
dalam kehidupan personalnya. Menetapnya perubahan positif menjadi keunggulan CBT-Religius. Religiusitas melalui kemampuan penyesuaian diri memiliki keterkaitan dengan subjective well being pada usia akhir dewasa madya. Keterkaitan ini menunjukkan bahwa kehidupan religi seseorang akan mengarahkan seseorang pada pengembangan kemampuan penyesuaian dirinya, sehingga dapat tercapai kondisi subjective well being (Hida, Suroso, \& Muhid, 2013).

Keuntungan adanya penambahan nilai religius dalam terapi kognitif perilakuan untuk meningkatkan kesejahteraan subjektif antara lain: klien menjadi lebih mudah menerima terapi, lebih termotivasi untuk berpartisipasi dalam terapi, meningkatkan efektivitas terapi dalam meningkatkan kesejahteraan subjektif dan membantu mempertahankan kesejahteraan subjektif pada pasien GGK.
Berdasarkan hal tersebut peneliti melakukan terapi kognitif perilakuan religius guna meningkatkan ke-sejahteraan subjektifpada pasien gagal ginjal kronik yang melakukan hemo-dialisis.

\section{METODE PENELITIAN}

\section{Desain Penelitian}

Adapun bentuk penelitian ini adalah kuasi eksperimen dengan menggunakan rancangan pretest-posttest control group design. Rancangan pretestposttest control group design adalah metode eksperimen yang berusaha untuk membandingkan efek suatu perlakuan terhadap variabel tergantung yang diuji dengan cara membandingkan keadaan variabel tergantung pada kelompok eksperimen setelah dikenai perlakuan dengan kelompok kontrol yang tidak dikenai perlakuan (Azwar, 2012).

Tabel 1. Rancangan eksperimen yang digunakan dalam penelitian ini

\begin{tabular}{ccccc}
\hline Kelompok & Prates & Perlakuan & Pascates & Tindaklanjut \\
\hline KE & O1 & X & O2 & O3 \\
KK & O1 & $-X$ & O2 & O3 \\
\hline
\end{tabular}

Keterangan :

$\begin{array}{llll}\text { KE } & \text { : Kelompokeksperimen } & \mathrm{O} 3 & : \text { Tindaklanjut } \\ \mathrm{KK} & \text { : Kelompokkontrol } & \mathrm{X} & : \text { Perlakuan } \\ \mathrm{O} 1 & : \text { Pengukuran prates } & -\mathrm{X} & : \text { Tanpa perlakuan } \\ \mathrm{O} 2 & : \text { Pengukuran pascates } & & \end{array}$




\section{Subjek Penelitian}

Subjek penelitian adalah penderita gagal ginjal kronis yang menjalani hemodialisis dengan kriteria sebagai berikut: beragama Islam, berjenis kelamin lakilaki/ perempuan, usia 22-45 tahun, pendidikan terakhir adalah SMA, menjalani proses hemodialisis $>6$ bulan, mempunyai skor rendah sampai sedang pada skala kepuasan hidup, bersedia secara sukarela mengikuti penelitian.

\section{Pengumpulan Data}

Pengumpulan data berikutnya dilakukan dengan menggunakan skala kesejahteraan subjektif. Pertama: The Satisfaction with Life Scale (SWLS). Skala ini disusun berdasarkan teori Diener, dkk (1985) yang terdiri atas 5 item dengan skor yang bergerak dari 1-7 (sangat tidak setuju hingga sangat setuju). Pada penelitian sebelumnya, instrumen ini sudah pernah diujicobakan kepada 50 orang Jawa. Setiap item diukur validitas dan reliabilitasnya dengan bantuan SPSS. Teknik yang digunakan adalah CronbachAlpha. Item ini memiliki item-total correlation minimal 0,3 dan koefisien alpha instrumen ini sebesar 0,83 (Gatari, 2008).

Kedua: Skala PANAS (Positive and Negative Afect Scale). Skala ini dimaksudkan untuk mengukur afek positif dan negatif terdiri atas 20 kata yang berkaitan dengan emosi dan atau perasaan. Skala ini dibuat oleh Watson, Clark \& Tellegen (1988) yang digunakan American Psychological Association (APA). Sebelum digunakan oleh peneliti, instrumen ini telah diuji cobakan di dalam penelitian yang dilakukan oleh Gatari kepada 50 responden yang berasal dari Jawa. Setelah data diperoleh kemudian dilakukan uji reliabilitas. Hasilnya menunjukkan instrumen ini reliable dengan koefisien alpha sebesar 0,91 (Gatari, 2008).

\section{Prosedur Intervensi}

Prosedur dalam penelitian ini meliputi beberapa tahapan penelitian, yaitu: Pertama: Persiapan penelitian meliputi analisis kebutuhan terkait permasalahan dalam penelitian (wawancara dan studi pustaka) serta pengurusan perizinan. Kedua: Penyusunan modul terapi kognitif perilakuan religius. Ketiga: Pengambilan data prates pada subjek penelitian (kelompok eksperimen dan kelompok kontrol) dilakukan untuk mendapatkan gambaran mengenai kesejahteraan subjektif pada pasien gagal ginjal kronis yang menjalani hemodialisis.

Keempat: Subjek penelitian (kelompok eksperimen) diberi terapi kognitif perilakuan religius dalam tiga kali pertemuan. Terapi diberikan oleh psikolog 
yang berpengalaman memberikan intervensi yang terkait dengan keislaman.
Kelima: Pelaksanaan Perlakuan. Berikut ini tabel yang berisi pelaksanaan perlakuan untuk subjek penelitian.

Tabel 2. Kegiatan Terapi Kognitif Perilakuan Religius

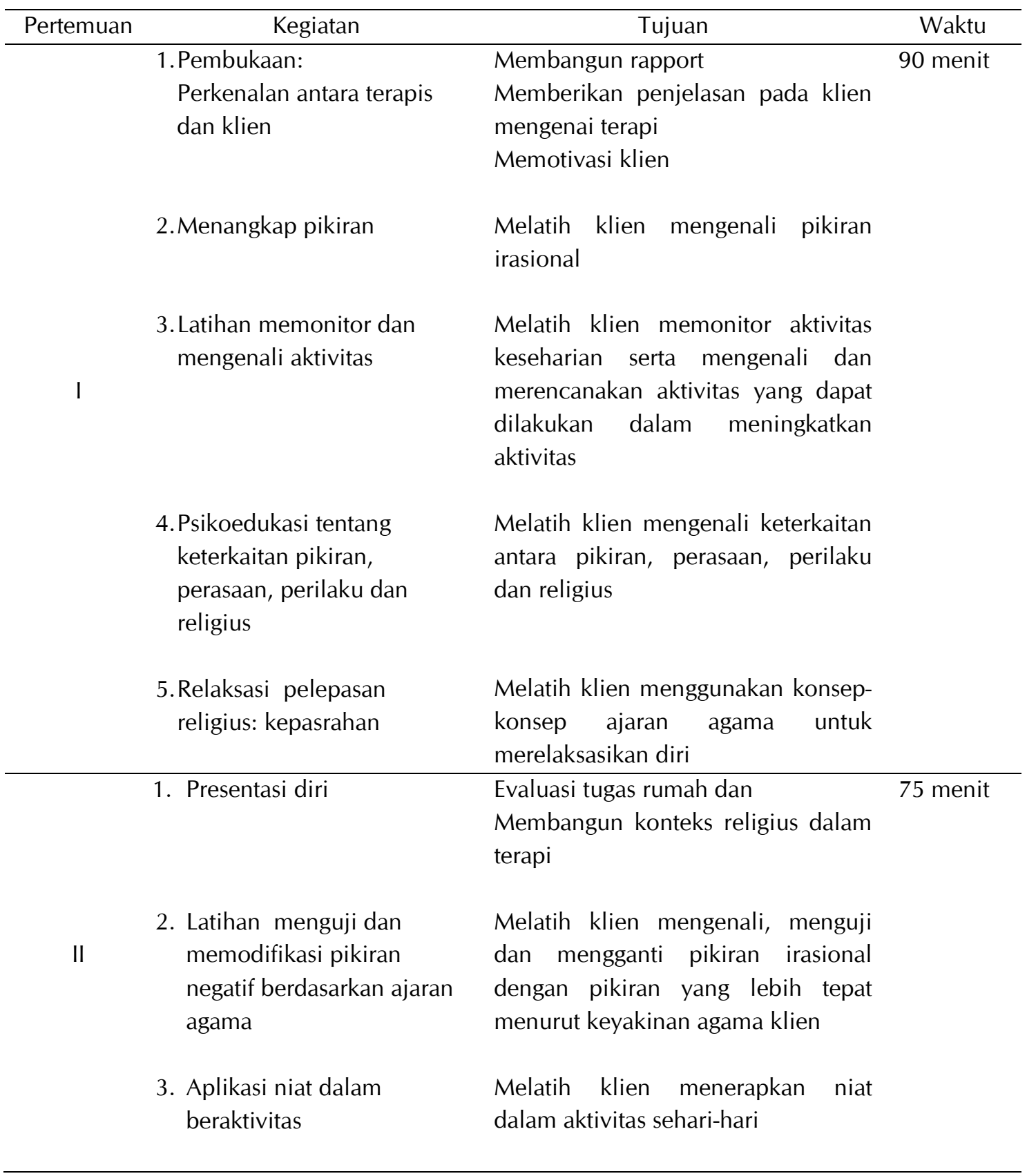




\begin{tabular}{|c|c|c|}
\hline & $\begin{array}{l}\text { 4. Relaksasi dengan isyarat } \\
\text { religius : doa }\end{array}$ & $\begin{array}{l}\text { Melatih klien menggunakan konsep- } \\
\text { konsep ajaran agama untuk } \\
\text { merelaksasikan diri }\end{array}$ \\
\hline \multirow{5}{*}{ III } & 1. Presentasi diri & $\begin{array}{l}\text { Evaluasi tugas rumah dan } 75 \text { menit } \\
\text { Membangun konteks religius dalam } \\
\text { terapi }\end{array}$ \\
\hline & 2. Melatih rasa syukur & $\begin{array}{l}\text { Melatih klien mensyukuri nikmat } \\
\text { dalam aktivitas keseharian }\end{array}$ \\
\hline & $\begin{array}{l}\text { 3. Pernyataan diri dengan } \\
\text { keyakinan agama }\end{array}$ & $\begin{array}{l}\text { Melatih klien mengatasi situasi } \\
\text { menekan dengan pernyataan diri } \\
\text { yang mendekatkan dengan Tuhan }\end{array}$ \\
\hline & $\begin{array}{l}\text { 4. Praktik Kebersyukuran: } \\
\text { Sujud Syukur }\end{array}$ & $\begin{array}{l}\text { Melatih klien menggunakan konsep } \\
\text { kebersyukuran dengan sujud syukur }\end{array}$ \\
\hline & 5. Terminasi & Mengakhiri terapi \\
\hline
\end{tabular}

Keenam: Pengambilan data pascates dilakukan setelah terapi selesai dilaksanakan. Selanjutnya pengambilan data tindak lanjut dilakukan dua minggu setelah terapi. Ketujuh: Tahapan akhir adalah melakukan analisis secara keseluruhan

\section{Teknik Analisis Data}

Metode analisis data yang digunakan dalam penelitian ini adalah analisis data kuantitatif dan kualitatif. Analisis data kuantitatif dalam penelitian ini menggunakan program International Business Machine Statistical Product and
76 Service Solution (IBM SPSS) 22.0 for windows. Jika data penelitian diterima melalui uji asumsi (normal dan homogen), maka pengujian hipotesis dalam penelitian ini dilakukan dengan analisis parametrik dengan teknik Independent Sample t-test digunakan untuk menguji perbedaan antara kelom-pok eksperimen dan kelompok kontrol setelah diberikan terapi kognitif perilakuan religius.

\section{HASIL PENELITIAN}

\section{Deskripsi Subjek Penelitian}


Tabel 3. Deskripsi Kepuasan Hidup (SWLS) Kelompok Eksperimen

\begin{tabular}{ccccccc}
\hline Subjek & JK & Prates & Pascates & $\begin{array}{c}\text { Tindak } \\
\text { Lanjut }\end{array}$ & $\begin{array}{c}\text { Gained } \\
\text { Score } \\
\text { (Pra- } \\
\text { Pasca) }\end{array}$ & $\begin{array}{c}\text { Gained } \\
\text { Score } \\
\text { (Pra- } \\
\text { Tindak } \\
\text { Lanjut) }\end{array}$ \\
\hline ES & L & 17 & 18 & 21 & 1 & 4 \\
DS & L & 13 & 13 & 16 & 0 & 3 \\
R & P & 15 & 17 & 21 & 2 & 6 \\
AD & P & 13 & 19 & 22 & 6 & 9 \\
\hline
\end{tabular}

Berdasarkan tabel 3, semua par- pada nilai kepuasan hidup. Peningkatan tisipan kelompok eksperimen dalam terlihat dari gained score pra-pasca dan penelitian ini mengalami peningkatan pra-tindak lanjut.

Tabel 4. Deskripsi Data Penelitian Skala Afek (PANAS) Kelompok Eksperimen

\begin{tabular}{ccccccc}
\hline Subjek & JK & Prates & Pascates & $\begin{array}{c}\text { Tindak } \\
\text { Lanjut }\end{array}$ & $\begin{array}{c}\text { Gained } \\
\text { Score } \\
\text { (Pra- } \\
\text { Pasca) }\end{array}$ & $\begin{array}{c}\text { Gained } \\
\text { Score } \\
\text { (Pra- } \\
\text { Tindak } \\
\text { Lanjut) }\end{array}$ \\
\hline ES & L & -1 & 14 & 16 & 15 & 17 \\
DS & L & -3 & 0 & 2 & 3 & 5 \\
R & P & -19 & -12 & 5 & 7 & 24 \\
AD & P & -2 & 8 & 9 & 10 & 11 \\
\hline
\end{tabular}

Berdasarkan tabel 4, semua partisi- peningkatan pada nilai afeksi. Hal ini pan kelompok eksperimen yang terdiri didasarkan gained score pra-pasca dan atas 4 orang subjek, 2 subjek laki-laki pra tindak lanjut keempat subjek. dan 2 subjek perempuan mengalami 
Tabel 5. Deskripsi Kepuasan Hidup (SWLS) Kelompok Kontrol

\begin{tabular}{ccccccc}
\hline Subjek & JK & Prates & Pascates & $\begin{array}{c}\text { Tindak } \\
\text { Lanjut }\end{array}$ & $\begin{array}{c}\text { Gained } \\
\text { Score } \\
\text { (Pra- } \\
\text { Pasca) }\end{array}$ & $\begin{array}{c}\text { Gained } \\
\text { Score (Pra- } \\
\text { Tindak } \\
\text { Lanjut) }\end{array}$ \\
\hline VR & P & 14 & 12 & 15 & -2 & 1 \\
L & L & 18 & 16 & 16 & -2 & -2 \\
S & L & 14 & 12 & 13 & -2 & -1 \\
E & P & 20 & 13 & 17 & -7 & -3 \\
\hline
\end{tabular}

Berdasarkan tabel 5, semua partisi- pascates. Kemudian pada gained score pan kelompok kontrol yang berjumlah 4 pra-tindak lanjut terlihat satu orang orang subjek yang terdiri atas 2 orang subjek yang mengalami peningkatan laki-laki dan 2 orang perempuan meng- skor, dan tiga orang subjek memiliki alami penurunan skor kepuasan hidup. penurunan skor kepuasan hidup diHal ini didasarkan pada gained score pra- bandingkan dengan prates.

Tabel 6. Deskripsi Afek (PANAS) Kelompok Kontrol

\begin{tabular}{ccccccc}
\hline Subjek & JK & Prates & Pascates & $\begin{array}{c}\text { Tindak } \\
\text { Lanjut }\end{array}$ & $\begin{array}{c}\text { Gained } \\
\text { Score } \\
\text { (Pra- } \\
\text { Pasca) }\end{array}$ & $\begin{array}{c}\text { Gained } \\
\text { Score } \\
\text { (Pra- } \\
\text { Tindak } \\
\text { Lanjut) }\end{array}$ \\
\hline VR & P & -11 & -10 & -13 & 1 & -2 \\
L & L & -3 & -5 & -9 & -2 & -6 \\
S & L & -5 & -8 & -8 & -3 & -3 \\
E & P & -6 & -9 & -12 & -3 & -6 \\
\hline
\end{tabular}

Berdasarkan tabel 6, pada gained score pra-pascates terlihat bahwa 1 orang subjek mengalami peningkatan afeksi dan tiga orang subjek mengalami penurunan afeksi. Pada gained score pratindak lanjut terlihat keempat orang subjek mengalami mengalami penurunan afeksi. 


\section{Hasil Uji Asumsi}

Tabel 7. Uji Normalitas Skala Kepuasan Hidup (SWLS)

\begin{tabular}{cccc}
\hline Kelompok & Perlakuan & $\mathbf{P}$ & Keterangan \\
\hline Eksperimen dan Kontrol & Prates & 0,$067 ;$ & Normal \\
& & $\mathrm{p}>0,05$ & \\
\hline
\end{tabular}

Berdasarkan tabel 7 diketahui hasil sebaran skor kepuasan hidup pada penelitian ini terdistribusi secara normal.

Tabel 8. Uji Normalitas Skala Afek (PANAS)

\begin{tabular}{cccc}
\hline Kelompok & Perlakuan & $\mathbf{P}$ & Keterangan \\
\hline Eksperimen dan Kontrol & Prates & 0,$099 ;$ & Normal \\
& & $\mathrm{p}>0,05$ & \\
\hline
\end{tabular}

Pada tabel 8 diketahui bahwa hasil sebaran skala afeksi (PANAS) berdistribusi normal $(p>0,05)$.

Tabel 9. Uji Homogenitas Data Penelitian Skala Kepuasan Hidup (SWLS)

\begin{tabular}{cccc}
\hline Kelompok & Levene Statistic & $\mathbf{p}$ & Keterangan \\
\hline Prates Eksperimen dan & 3,000 & 0,$134 ;$ & Normal \\
Kontrol & & $\mathrm{p}>0,05$ & \\
\hline
\end{tabular}

Pada tabel 9 hasil analisis pada dapat dikatakan bahwa tidak ada skala kepuasan hidup (SWLS) subjek perbedaan varians data pada saat prates penelitian menunjukkan nilai Levene kelompok eksperimen dan kelompok statistic 3,000 dengan $\mathrm{p}=0,134$ kontrol pada subjek penelitian. $(p>0,05)$. Berdasarkan kaidah, maka 
Tabel 10. Uji Homogenitas Data Penelitian Skala Afek (PANAS)

\begin{tabular}{cccc}
\hline Kelompok & Levene Statistic & $\mathbf{p}$ & Keterangan \\
\hline Prates Eksperimen dan & 2,808 & 0,$145 ;$ & Normal \\
Kontrol & & $\mathrm{p}>0,05$ & \\
\hline
\end{tabular}

Pada tabel 10 hasil analisis pada skala afek (PANAS) subjek penelitian menunjukkan nilai Levene statistic 2,808 dengan $p=0,145(p>0,05)$. Berdasarkan kaidah, maka dapat dikatakan bahwa tidak ada perbedaan varians data pada saat prates kelompok eksperimen dan kelompok kontrol pada subjek penelitian.

\section{Hasil Uji Hipotesis}

Tabel 11. Data Perbandingan Hasil Uji Hipotesis Skala Kepuasan Hidup

\begin{tabular}{lccc}
\hline \multicolumn{1}{c}{ Perhitungan } & t & Sig. (p) & Kesimpulan \\
\hline Selisih skor Prates-Pascates & 3,031 & 0,023 & Signifikan \\
Selisih skor Pascates-Tindak Lanjut & 4,287 & 0,005 & Signifikan \\
\hline
\end{tabular}

Hasil uji independent sample t-test skala kepuasan hidup pada kelompok eksperimen dan kelompok kontrol pada saat prates dan pascates adalah $t=3,031$, $=0,023(p<0,05)$ artinya terdapat perbedaan kepuasan hidup pada kelompok eksperimen dan kelompok kontrol. Selanjutnya hasil uji independent sample t-test skala kepuasan hidup pada kelompok eksperimen dan kelompok kontrol pada saat prates dan tindak lanjut adalah $t=4,287, \quad p=0,005 \quad(p<0,01)$ artinya terdapat perbedaan kepuasan hidup pada kelompok eksperimen dan kelompok kontrol setelah dua minggu dari pemberian intervensi berakhir (tindak lanjut). Hasil menunjukkan bahwa terdapat perbedaan kepuasan hidup yang signifikan setelah diberikan terapi kognitif perilakuan religius. Dengan demikian terapi kognitif perilakuan religius berpengaruh terhadap peningkatan kepuasan hidup para pasien gagal ginjal kronis. 
Tabel 12. Data Perbandingan Hasil Uji Hipotesis Skala Afek (PANAS)

\begin{tabular}{lccc}
\hline \multicolumn{1}{c}{ Perhitungan } & t & Sig. $(\mathbf{p})$ & Kesimpulan \\
\hline Selisih skor Prates-Pascates & 3,888 & 0,008 & Signifikan \\
Selisih skor Pascates-Tindak Lanjut & 4,407 & 0,005 & Signifikan \\
\hline
\end{tabular}

Hasil uji independent sample t-test skala Afek pada kelompok eksperimen dan kelompok kontrol pada saat prates dan pascates adalah $\mathrm{t}=3,888, \mathrm{p}=0,008$ $(p<0,01)$ artinya terdapat perbedaan nilai afek pada kelompok eksperimen dan kelompok kontrol sebelum dan sesudah pemberian terapi kognitif perilakuan religius. Selanjutnya hasil uji independent sample t-test skala afek pada kelompok eksperimen dan kelompok kontrol pada saat prates dan tindak lanjut adalah $\mathrm{t}=4,407, \quad \mathrm{p}=0,005$ $(p<0,01)$ artinya terdapat perbedaan nilai afek pada kelompok eksperimen dan kelompok kontrol setelah dua minggu dari pemberian intervensi berakhir (tindak lanjut). Hasil menunjukkan bahwa terapi kognitif perilakuan religius memiliki pengaruh yang signifikan terhadap nilai afeksi pasien gagal ginjal kronis hingga masa tindak lanjut berakhir.

\section{PEMBAHASAN}

Penelitian ini bertujuan untuk mengetahui pengaruh terapi kognitif perilakuan religius terhadap peningkatan kesejahteraan subjektif pada pasien gagal ginjal kronis yang menjalani hemodialisis. Hasil yang diperoleh dalam penelitian ini menunjukkan bahwa terapi kognitif perilakuan religius berpengaruh dalam peningkatan kesejahteraan subjektif pada pasien gagal ginjal kronis yang menjalani hemodialisis. Hasil penelitian menunjukkan bahwa terjadi perbedaan rerata gain score kesejahteraan subjektif setelah diberi perlakuan berupa terapi kognitif perilakuan religius pada kelompok eksperimen dan kelompok kontrol yang tidak diberikan perlakuan pada pasien gagal ginjal kronis yang menjalani hemodialisis.

Pada penelitian ini, kesejahteraan subjektif terdiri atas 2 aspek yaitu kepuasan hidup yang diukur dengan skala kepuasan hidup atau Satisfaction with Life Scale (SWLS) dan aspek afeksi yang diukur dengan Positive Affect and Negative Affect Schedule (PANAS). Berdasarkan analisis data yang dilakukan pada kesejahteraan subjektif pasien gagal ginjal kronis yang menjalani hemodialisis menunjukkan bahwa terdapat perbedaan 
kesejahteraan subjektif antara kelompok eksperimen yang diberikan perlakuan terapi kognitif perilakuan religius dan kelompok kontrol yang tidak diberikan perlakuan.

Berdasarkan hasil analisis uji beda independent sample t-test pada perubahan nilai kepuasan hidup diketahui bahwa terdapat perubahan signifikan pada saat sebelum dilaksanakan terapi kognitif perilakuan religius dan setelah terapi (pra-pasca) antara kelompok eksperimen dan kelompok kontrol dengan $t=3,031$, $p=0,023 \quad(p<0,05)$. Selanjutnya pada saat sebelum pelaksanaan terapi kognitif perilakuan religius dan pada saat tindak lanjut (pra-tindak lanjut) didapat nilai $t=4,287, \quad p=0,005 \quad(p<0,01) . \quad$ Hal tersebut menunjukkan bahwa ada perbedaan yang signifikan pada tingkat kepuasan hidup pasien gagal ginjal kronis antara kelompok eksperimen dan kelompok kontrol.

Pada skala afeksi hasil analisis uji beda independent sample t-test pada perubahan nilai afeksi kelompok eksperimen dan kelompok kontrol pada saat sebelum dilaksanakan terapi kognitif perilakuan religius dan setelah terapi (pra-pasca) yakni $\mathrm{t}=3,888, \quad \mathrm{p}=0,008$ $(p<0,01)$. Selanjutnya pada saat sebelum pelaksanaan terapi kognitif perilakuan religius dan pada saat tindak lanjut (pra- tindak lanjut) didapat nilai $\mathrm{t}=4,407$, $p=0,005(p<0,01)$. Hal tersebut menunjukkan bahwa ada perbedaan yang signifikan pada tingkat afeksi pasien gagal ginjal kronis antara kelompok eksperimen dan kelompok kontrol pada saat dilakukannya tindak lanjut.

Hasil analisis di atas menunjukkan bahwa pada pasien gagal ginjal kronis yang menjalani hemodialisis dan mendapat perlakuan terapi kognitif perilakuan religius mengalami peningkatan kesejahteraan subjektif dilihat dari dua aspek yaitu kepuasan hidup dan aspek afeksi dibandingkan dengan pasien gagal ginjal kronis yang tidak mendapatkan terapi kognitif perilakuan religius. Hal ini juga didukung oleh hasil-hasil penelitian Wang dan Chen (2012) bahwa terapi kognitif perilaku efektif dapat meningkatkan kualitas hidup pasien gagal ginjal kronis yang menjalani hemodialisis dan juga dapat meningkatkan kualitas tidur juga menurunkan kecemasan dan depresi.

Berdasarkan hasil analisis data kualitatif, yaitu dari hasil observasi dan wawancara selama proses terapi menunjukkan bahwa terapi kognitif perilakuan religius secara signifikan berpengaruh dalam meningkatkan kesejahteraan subjektif pada pasien gagal ginjal kronis yang menjalani hemodialisis. terapi 
kognitif perilakuan religius memberi bantuan kepada pasien untuk dapat mengubah pikiran atau keyakinan negatif, irasional dan mengalami penyimpangan menjadi lebih positif dan rasional sehingga secara bertahap akan merubah perilaku menjadi lebih sehat dan normal (Hepple, 2004).

Selain itu, peneliti menggunakan teknik kebersyukuran, serta pernyataan diri dengan keyakinan agama dalam proses restrukturisasi kognitif. Hal ini sejalan dengan kondisi subjek penelitian yang banyak memiliki pikiran negatif sehingga memengaruhi subjek dalam kehidupan sehari-harinya yang lebih banyak memunculkan afek negatif. Selain itu, pikiran negatif yang membuat subjek penelitian menjadi cemas, khawatir, malu dan lain sebagainya yang berdampak pula pada proses pengobatan subjek. Setelah menyadari bahwa pikiran subjek tersebut adalah negatif dan memperoleh pikiran alternatif yang lebih positif, subjek saat ini mampu meningkatkan kepuasan hidup dan afek positifnya untuk lebih semangat dan optimis dalam menjalani kehidupan. Pada sesi melatih rasa syukur, subjek diminta untuk menuliskan hal-hal yang disyukuri dan bagaimana cara untuk mensyukurinya. Hal ini sesuai dengan penelitian Emmons dan McCullough (2003) menemukan bahwa individu yang menuliskan hal-hal yang disyukuri memiliki tingkat kesejahteraan subjektif yang lebih tinggi.

Pada dasarnya religiusitas memiliki pengaruh terhadap kesehatan mental dan fisik dimana religiusitas dapat membantu coping stress, kelelahan dan kematian pada individu (Pledmont, 2009). Terapi perilaku dirancang untuk meningkatkan aktivitas sehingga memunculkan perilaku yang mampu membuat subjek puas dan bahagia serta ditujukan dalam kerangka keyakinan beragama yang diharapkan akan memunculkan perilaku yang sesuai dengan yang diniatkan. Hal ini sejalan dengan penelitian sebelumnya dimana keyakinan beragama dan praktek beragama dapat meningkatkan kualitas hidup dan kesejahteraan subjektif pada mahasiswa Muslim (Abdel-Khalek, 2010). Teknik perilaku dalam sesi apikasi niat dalam beraktivitas, relaksasi religius dan praktiksujud syukur membantu klien secara lebih mudah dalam pemahaman materi yang disampaikan. Hal ini juga berdampak pada menurunnya ketegangan yang dirasakan subjek dalam menghadapi sakit gagal ginjal kronis yang dideritanya.

Desain penelitian ini menggunakan aktivitas-aktivitas pembelajaran melalui pengalaman (experiental learning) yakni pembelajaran melalui pengalaman, 
proses pembelajaran menjadi efektif karena individu mendapatkan stimulasi yang berulang melalui berbagai indera, baik penglihatan, pendengaran, pengecapan, penciuman dan perabaan (Johnson dan Johnson, 2009). Pada penelitian kali ini subjek diberikan tugas rumah berupa mengontrol aktivitas serta memaknainya dan mengidentifikasi pikiran otomatis yang muncul lalu digantikan dengan pemikiran alternatif yang lebih positif yang berguna untuk restukturisasi kognitif pada subjek dan memaknai halhal yang dapat disyukuri.

Berdasarkan hasil data kualitatif diketahui pula, bahwa peningkatan kesejahteraan subjektif subjek berbedabeda. Hal tersebut terlihat dari peningkatan nilai kepuasan hidup dan afeksi yang berbeda dari setiap subjek. Perbedaan tersebut dipengaruhi oleh perbedaan dari setiap subjek dalam memaknai dan mengaplikasikan materi terapi yang telah diberikan. Ada subjek yang mempraktekkan materi yang telah disampaikan secara keseluruhan dan ada juga subjek yang baru mempraktekkannya sebagian, selain itu faktor dari dukungan sekitar subjek juga memengaruhi hasil dari penelitian ini.

Hasil dari penelitian ini juga mendukung penelitian-penelitian sebelumnya mengenai peningkatan kesejah- teraan subjektif pada pasien sakit kronis. Krisnawati (2015) dan Rahmanita (2016) menjelaskan dalam penelitiannya bahwa pelatihan kebersyukuran memiliki pengaruh terhadap kesejahteraan subjektif pada penderita diabetes mellitus tipe 2 dan pasien hipertensi. Kebersyukuran merupakan salah satu bagian dari religiusitas yang digunakan di sesi terapi kognitif perilakuan religius dalam penelitian ini.

Keberhasilan terapi kognitif perilakuan religius ini didukung oleh antusiasme, motivasi dan penerimaan yang baik dari subjek. Hal ini dapat dilihat dari intensitas kehadiran subjek, peran aktif dalam berpendapat dan memberikan umpan balik. Hal tersebut juga didukung berdasarkan hasil evaluasi terapi kognitif perilakuan religius dimana subjek mendapat tambahan informasi, wawasan dengan seluruh informasi yang diberikan sehingga lebih termotivasi untuk menjalankan pengobatan dan pola hidup yang lebih sesuai dengan anjuran dokter. Para subjek terdorong untuk membiasakan diri mengutamakan pikiran dan perasaan positif dengan selalu bersyukur dan pasrah pada setiap kondisi apapun.

Berdasarkan penjelasan di atas, dapat disimpulkan bahwa hipotesis dalam penelitian ini terpenuhi. Pertama, hasil penelitian ini membuktikan bahwa 
terdapat peningkatan nilai kepuasan hidup pada pasien gagal ginjal yang menjalani hemodialisis yang mendapatkan terapi kognitif perilakuan religius dibandingkan dengan pasien gagal ginjal kronis yang tidak mendapatkan perlakuan. Kedua, terdapat peningkatan pada nilai afeksi pada pasien gagal ginjal kronisyang diberikan terapi kognitif perilakuan religius dibandingkan dengan pasien gagal ginjal kronis yang tidak mendapatkan perlakuan. Ketiga, terdapat perbedaan nilai kesejahteraan subjektif pada pasien gagal ginjal kronis yang diberikan terapi kognitif perilakuan religius dibandingkan dengan kelompok pasien gagal ginjal kronis yang tidak mendapatkan perlakuan.

Penelitian ini juga memiliki beberapa kekurangan, seperti jumlah pertemuan yang masih dirasa kurang oleh subjek penelitian karena waktu untuk diskusi perlu ditambahkan lebih lama lagi. Dalam hal mengontrol subjek penelitian untuk mengikuti aturan dalam terapi kognitif perilakuan religius secara benar juga dirasa sulit karena perubahan sikap biasanya digerakkan oleh emosi dengan cara yang positif dan atau negatif (Wulandari, 2015). Selain itu, bentuk intervensi yang dilakukan secara berkelompok lebih efektif diberikan kepada individu yang memiliki kemampuan komunikasi yang aktif dan lebih terbuka. Sedangkan pada saat penentuan subjek penelitian peneliti menentukan berdasarkan kategorisasi kesejahteraan subjektif dan kesediaan subjek untuk mengikuti proses terapi.

\section{SIMPULAN DAN SARAN}

\section{Simpulan}

Berdasarkan hasil penelitian yang telah dilakukan, maka dapat disimpulkan bahwa terapi kognitif perilakuan religius dapat meningkatkan kesejahteraan subjektif pada pasien gagal ginjal kronis yang menjalani hemodialisis. Kelompok yang mendapat terapi kognitif perilakuan religius lebih tinggi kesejahteraan subjektifnya dibandingan kelompok yang tidak mendapatkan terapi kognitif perilakuan religius.

\section{Saran}

Penelitian ini telah dilakukan semaksimal mungkin, namun tidak menutup kemungkinan masih terdapat kekurangan. Oleh karena itu, peneliti memberikan saran sebagai berikut. Pertama: Saran bagi subjek penelitian. Diharapkan dapat menerapkan, membiasakan dan meningkatkan hal-hal yang telah didapatkan dalam proses terapi, seperti penerapan modifikasi pikiran negatif dan 
mengenali aktivitas. Pada sesi tersebut, beberapa subjek masih kesulitan untuk modifikasii pikiran negatifnya menjadi pikiran alternatif yang lebih positif dan berlandaskan nilai agama. Sehingga disarankan kepada seluruh subjek untuk dapat lebih memiliki pemikiran yang lebih positif dan dapat memaknai aktivitas yang dilakukan berlandaskan nilai agama sehingga subjek dapat menjalankan kehidupan yang lebih positif dan optimis.

Kedua: Saran bagi penelitian selanjutnya. Peneliti yang ingin mela-kukan penelitian serupa, diharapkan (a) dapat meneliti terapi kognitif perilakuan religius secara individu untuk melihat perkembangan subjek dari hari ke hari dan lebih dapat mengontrol tugas rumah yang diberikan. (b) Peneliti berharap untuk terapi kognitif perilakuan religus berikutnya juga dapat menambahkan banyaknya jumlah pertemuan sehingga kesempatan para subjek untuk berdiskusi jauh lebih besar. (c) Peneliti selanjutnya juga dapat meneliti kefektifitasan terapi kognitif perilakuan religius terhadap pasien penyakit-penyakit lainnya serta dapat digunakan untuk dapat meningkatkan variabel lain yang berhubungan dengan kehidupan pasien sakit kronis seperti penerimaan diri, kecemasan dan juga resiliensi.
Ketiga: Saran bagi pihak rumah sakit. Manfaat dalam penelitian ini juga dapat menjadi masukan bagi setiap pusat layanan kesehatan bahwa terapi kognitif perilakuan religius dapat meningkatkan kesejahteraan subjektif pada pasien gagal ginjal. Dengan demikian, diharapkan pihak Rumah Sakit dapat memberikan kegiatan berkelanjutan bagi para pasien gagal ginjal lainnya.

\section{DAFTAR PUSTAKA}

Abdel-Khalek, A.M. (2010). Quality of life, subjective well-being, and religiousity in muslim college students. Quality of Life Research, 19, 1133-1143.

Ancok, D \& Suroso, F.N. (2011). Psikologi Islami. Yogyakarta: Pustaka Pelajar.

Azwar. S. (2012). Penyusunan Skala Psikologi; Edisi 2. Yogyakarta: Pustaka Pelajar.

Cahyareni, L. (2014). Efektivitas Pelatihan Kebersyukuran dengan Metode Dzikir untuk Meningkatkan Subjective Well Being pada Pasien Gagal Ginjal. Tesis (tidak diterbitkan). Yogyakarta: Fakultas Psikologi dan Ilmu Sosial Budaya Universitas Islam Indonesia. 
Emmons, R.A., \& McCullough, M.E. (2003). Counting blessings versus burdends: an experimental investigation of gratitude and subjective well being in daily life. Journal of Personality and Social Psychology, 84 (2),377-389.

Foreze, Martin, Patton, Zadeh and Kopple, (2010)

Hepple, J. (2004). Psychoterapies with older people: an oveview. Advance in Psychiatric Treatment, 10, 371377

Hida,S., Suroso, \& Muhid,A.(2013). Hubungan antara Religiusitas dengan Subjective Well Being melalui Kemampuan Penyesuaian diri pada Akhir Dewasa Madya. academia.edu http://www.academia.edu/4472682 /Hubungan_antara_Religiusitas_de ngan_Subjective_Well_Being_mela lui_Kemampuan_Penyesuaian_diri _pada_akhir_dewasa_madya (diunduh 3 Mei 2015)

Johnson, D.W \& Johnson, F.P. (2009). Joining Together: Group Therapy and Group Skills. 9th Ed. New Jersey: Person Education Inc

Kementrian Kesehatan RI. (2013). Riset Kesehatan Dasar 2013. Jakarta: Badan Penelitian Dan Pengembangan Kesehatan
Krisnawati, E. (2015). Efektivitas Pelatihan Kebersyukuran untuk Meningkatkan Kesejahteraan Subjektif pada Penderita Diabetes Mellitus Tipe II. Tesis (tidak diterbitkan). Yogyakarta: Fakultas Psikologi dan Ilmu Sosial Budaya Universitas Islam Indonesia

Mansjoer, A. 2000. Kapita Selekta Kedokteran. Jakarta: Media Aesculapius.

McCullough, M.E \& Larson, D. B. (1999). Prayer, In W, R. Miller (Ed), Intergrating Spirituality into Treatment; Resourcesfor Practitioners. Washington, D. C: American Psychological Association

Pledmont, R.L. (2009). The Contribution of Religiousness and Spirituality to Subjective Well-being and Satisfaction with Life(Chapter 5). In Souza, M., Francis, L.J., O'HigginsNorman, J., \& Scott, D.G (Edited). International Handbook of Education for Spirituality, Care and Wellbeing, 89-105.New York: Springer

Rahmanita, A. (2016). Efektivitas Pelatihan Kebersyukuran untuk Meningkatkan Kesejahteraan Subjektif pada Penderita Penyakit Hipertensi. Tesis (tidak diterbitkan). Yogyakarta: Fakultas Psikologi dan Ilmu Sosial Budaya Universitas Islam Indonesia 
Sadif, R.S. (2013). Pengaruh Terapi Relaksasi Zikir untuk Menurunkan Tingkat Stres pada Pasien Gagal Ginjal Kronik yang menjalani Hemodialisis di RSUD X. Tesis (tidak diterbitkan). Yogyakarta: Fakultas Psikologi dan Ilmu Sosial Budaya Universitas Islam Indonesia

Safitri, R.P. (2013). Gratitude Cognitive Behavior Therapy (G-CBT) untuk Meningkatkan Penerimaan Diri pada Pasien Gagal Ginjal Kronik yang Menjalani Hemodialisis. Tesis (tidak diterbitkan). Yogyakarta: Fakultas Psikologi dan Ilmu Sosial Budaya Universitas Islam Indonesia

Safitri, R.P, \& Sadif, R. S. (2013). Spiritual Emotional Freedom Technique (SEFT) to Reduce Depression for Chronic Renal Failure Patients in Cilacap Hospital to Undergo Hemodialysis. International Journal of Social Science and Humanity, 3 (3), 300-302.
Sundel, M. \& Sundel, S.S. (2005). Behavior Change in the Human Service. California: Sage

Utami, M. S. (2012). Religiusitas, Koping Religius, dan Kesejahteraan Subjektif. Jurnal Psikologi (UGM). 39 (1), 46-66.

Wang, L \& Chen, C. (2012). The Psychological Impact of Hemodialysis on Patients with Chronic Renal Failure. In Polenakovic, M (Editor). Renal Failure - The Facts (217-236). InTech di unduh http://www.intechopen.com/books/ renal-failure-the-facts/thepsychological-impact-

ofhemodialysis -on-patients-withchronic-renal-failure

Wulandari, E.D. (2015). Terapi Kognitif Perilaku Insomnia untuk Mengurangi Tingkat Insomnia Psikogenik pada Mahasiswa. Tesis (tidak diterbitkan). Yogyakarta: Fakultas Psikologi dan Ilmu Sosial Budaya Universitas Islam Indonesia 